\title{
Cybersecurity in the Making - Policy and Law: a Case Study of Georgia
}

\author{
Vladimeri Napetvaridze \\ Ivane Javakhishvili Tbilisi State University, Georgia \\ lado.nafetvaridze@gmail.com
}

Archil Chochia

TalTech Law School, Tallinn University of Technology, Estonia archil.chochia@taltech.ee

NAPETVARIDZE, Vladimeri; CHOCHIA, Archil. Cybersecurity in the Making - Policy and Law: a Case Study of Georgia. International and Comparative Law Review, 2019, vol. 19, no. 2, pp. 155-180. DOI: 10.2478/iclr-2019-0019.

\begin{abstract}
Summary: The given article is an evaluation of the implementation and development of Georgia's cybersecurity policy, and its influence on Georgia's global cybersecurity index. The study covers the period from 2008 to 2018. In 2008 Georgia became one of the first victims of hybrid warfare. During the August 2008 Russo-Georgian war, Georgian government websites were attacked by hackers affiliated with Russia. In the given period, cybersecurity was not the priority direction for Georgia, therefore government portals were easy targets for cybercriminals and the government couldn't prevent the cyberattacks. After 2008, the government decided to develop a state cybersecurity policy. In 2012 the country ratified the Council of Europe's cybersecurity convention. At the same time, the "Law of Georgia on Information Security" which had become a basic document of the cybersecurity state policy implementation, had been adopted. The document was followed by a cybersecurity strategy. During the following years, based on cybersecurity strategy document, Georgia implemented 2 action plans and defined the relevant state agencies responsible for "cyber safety" of the country. As a result of the reforms, in 2017, according to the International Telecommunication Union (ITU) Cybersecurity Global Index, Georgia has been ranked among the top ten countries. The given article is a chronological description of a Georgian cyberpolicy and cybercapabilities evolution. It includes cases of organized cybercrime carried out against the state and examples of the development of Georgian cybersecurity policy which was reflected on the global international cybersecurity index of the country.
\end{abstract}

Keywords: Georgia; Cybersecurity; International telecommunication union; Ranking

\section{Introduction - The role of cybersecurity}

The 21 st century is considered as the era of digital technologies. The process of "internetization" has covered all areas of human life. The world is completely dependent on electronic technologies. The most important political, economic 
and social projects are carried out via the internet. Digital technologies are used to manage important strategic objects; therefore, the security of cyberspace is as important for the countries as land, sea and air defence. ${ }^{1}$ The more developed state is, the more it depends on the digital technologies; therefore, the importance of cybersecurity is tremendous. ${ }^{2}$ Insecure computer systems may lead to catastrophic results. ${ }^{3}$

According to International Telecommunications Union's (ITU) definition: "Cybersecurity is the collection of tools, policies, security concepts, security safeguards, guidelines, risk management approaches, actions, training, best practices, assurance and technologies that can be used to protect the cyber environment and organization and user's assets. Organization and user's assets include connected computing devices, personnel, infrastructure, applications, services, telecommunications systems, and the totality of transmitted and/or stored information in the cyber environment. Cybersecurity strives to ensure the attainment and maintenance of the security properties of the organization and user's assets against relevant security risks in the cyber environment. The general security objectives comprise the following:

- Availability;

- Integrity, which may include authenticity and non-repudiation;

- Confidentiality."

In the 21st century, many countries defined cybersecurity as part of the National Security Strategy. The main function of the state, that everyone agrees on, is to maintain the safety of its citizens, and in the digital era, the security of a citizen's electronic profile has become as important as physical, economic and social wellbeing. ${ }^{5}$ Internet has become a key instrument of communication among individuals, a large part of citizens manages finances through the Inter-

1 RIOS, Billy. Sun Tzu was a hacker: An examination of the tactics and operations from a real world cyber attack. In: CZOSSEC, Christian \& Geers, Kenneth (Eds.) The Virtual Battlefield: Perspectives on Cyber Warfare, 2009, vol. 3, pp. 143-155; DUNN CAVELTY, Myriam. Europe's cyber-power. European Politics and Society, 2018, vol. 19, no. 3, pp. 304-320.

2 BEBBER, Robert "Jake", Cyber power and cyber effectiveness: An analytic framework. Comparative Strategy, 2017, vol. 36, no. 5, pp. 426-436.

3 CHEE-WOOI, Ten. CHEN-CHING, Liu. GOVINDARSU, Manimaran. "Vulnerability assessment of cybersecurity for SCADA systems." IEEE Transactions on Power Systems, 2008, vol. 23, no. 4, pp. 1836-1846; VALUCH, Jozef; GÁBRIŠ, Tomáš, HAMULÁK, Ondrej. Cyber attacks, information attacks, and postmodern warfare. Baltic Journal of Law \& Politics, 2017, vol. 10, no. 1, pp. 63-89.

4 International Telecommunication Union. Definition of cybersecurity. Online; Available at: https://www.itu.int/en/ITU-T/studygroups/com17/Pages/cybersecurity.aspx; Accessed: 15.09.2019.

5 DE BRUIJN, Hans \& JANSSEN, Marijn. Building cybersecurity awareness: The need for evidence-based framing strategies. Government Information Quarterly, 2017, vol. 34, no. 1, pp. 1-7. 
net, therefore an insufficient defense of cyberspace can lead to a huge material loss. ${ }^{6}$

The role of cybersecurity is even more crucial in the countries where establishing e-governance is the priority of the state policy. E-governance is a modern way for bilateral communication between government and society through digital technologies. ${ }^{7}$ There are following important aspects to be fulfilled, in order to implement e-governance:

- Political Will ${ }^{8}$ - government should be prepared to implement digital technologies, and create Web portals to provide services electronically;

- ICT - infrastructure ${ }^{9}$ - citizens should have access to the Internet, because without the Internet it is impossible to use digital services offered by the government;

- Society Readiness level. ${ }^{10}$
A) Public awareness about e-services;
B) Trust towards E-services;
C) Skills to use e-service;

In order to implement bilateral digital communication between government and population, citizens should have information about e-services offered by state institutions, and trust towards these services. Consequently, cybersecurity has crucial importance for maintaining the proper functioning of digital services $^{11}$, therefore it plays a huge role in the process of defining the public opinion regarding e-governance issues.

If there is no trust towards the digital services offered by the government, citizens will not use this state of art tool for communication and they will prefer traditional forms. In order to increase awareness of population towards e-services, implementation of information campaign is needed. Citizens should have information about the benefits and safety of the government e-services. From

6 KERIKMÄE, Tanel \& RULL, Addi. The Future of Law and eTechnologies, 2016. SpringerVerlag Heidelberg; KERIKMÄE, Tanel, HOFFMANN, Thomas, CHOCHIA, Archil. Legal Technology for Law Firms: Determining Roadmaps for Innovation. Croatian International Relations Review, 2018, vol. 24, pp. 91-112.

7 PALVIA, Shailendra. \& SHARMA, Sushil. E-government and e-governance: definitions/ domain framework and status around the world. In International Conference on E-governance, 2007, pp. 1-12.

8 AMORETTI, Francesco. ICTs Policies: E-Democracy and E-Government for Political Development, 2007.

9 MADON, Shirin. Evaluating the developmental impact of e-governance initiatives: An exploratory framework. The Electronic Journal of Information Systems in Developing Countries, 2004, vol. 20, no. 1, pp. 1-13.

10 HEEKS, Richard. Understanding e-governance for development. Manchester: Institute for Development Policy and Management, 2001.

11 TOLBERT, Caroline J., and MOSSBERGER, Karen. "The effects of e-government on trust and confidence in government." Public administration review, 2006, vol. 66, no. 3, pp. 354-369. 
this point of view, cybersecurity has a crucial role in the process of e-governance implementation, because if "customers" of e-services aren't sure that the cybersafety is granted, the idea of establishing e-governance will fail at the very beginning.

Consequently, in recent years, special attention has been paid to the cybersecurity issue, because it is not only the important part of National Security Strategies, but it is one of the main aspects defining the public opinion towards e-services.

Research of the National cybersecurity state strategy (NCSS) has become one of the most important topics of cyber power researches. Group of scientists evaluated theoretical methodology for NCSS comparison and compared ten countries national cybersecurity state strategies. ${ }^{12}$ Others discuss public-private relations in the lights of National cybersecurity state strategy. ${ }^{13}$

In the given article Georgian NCSSs will be analysed as a cornerstone of the Georgian cybersecurity development and its influence on Georgia's ranking in the international cybersecurity rankings.

\section{Research Methodology}

According to the fact, that the main goal of the given article was to describe the chronology of Georgian cybersecurity development and to evaluate how the cybersecurity state policy implementation was reflected into the international cybersecurity rankings of Georgia, the study combines several methodologies, among them: case study model, comparative analyses and analyses of international surveys results as a secondary source.

In order to define Georgia cybersecurity capabilities, in the framework of the article the cases of well-known cyber-incidents will be analyzed.

How did they influence the state policy of cybersecurity and how the country's cyber defensive model has been developed? All off the mentioned cases, using the "case study" model, will be analysed from the state policy and legislation point of view.

In addition, to provide a clear picture of Georgian cybersecurity potential, the results of the international cybersecurity Survey, provided by the International Telecommunication Union (ITU) will be analysed and the most vulnerable aspects of Georgian cybersecurity will be defined according to ITU. At the next stage, the National Cybersecurity Strategies Evaluation Tool, created by The European Union Agency for Cybersecurity (ENISA), will be used to evaluate the

12 LUIIJF, Eric, BESSELING, Kim, SPOELSTRA, Maartje, GRAAF, Patrick. Ten National Cyber Security Strategies: a Comparison: Critical Information Infrastructure Security, 2013.

13 CARR, Madeline. Public-private partnerships in national cyber-security strategies. International Affairs, 2016, vol. 92, no. 1, pp. 43-62. 
most vulnerable aspects of Georgia's cybersecurity strategy and elaborate recommendations.

In general, the chronological analysis of Georgian cybersecurity development and the dynamics of the process can be assumed as a measure to fill a gap, caused by a shortage of English language literature about the given topic.

The article includes the cases of cyber incidents and cybercrimes carried out against Georgia and the government's legislative reforms as a response, to increase the cybersecurity capabilities of the state. It will also reflect the influence of those reforms on the state's cybersecurity global index.

\section{Case of Georgia}

\subsection{Background}

Georgia is a South Caucasus republic, which re-gained independence in 1991, after Soviet occupation. Civil war, hard social and economic conditions have hindered country's development. ${ }^{14}$ There was no state strategy of internet development nor e-governance establishment action plans. This was one of the main reasons for cybersecurity failure in 2008 during the August War. In 2011, Georgia joined the international project: Open Government Partnership (OGP), the main goal of which was to support states to establish an open and accountable government via implementing governmental electronic services. ${ }^{15}$

In 2012, the government adopted the first OGP action plan, which considered an introduction of more than 20 e-services. In total, Georgia has already carried out 3 action plans and implemented dozens of e-services.

The state policy of establishing e-governance has given the results and it was reflected in the UN's e-governance surveys. According to the results of UN 2010 research Georgia took the $102^{\text {nd }}$ place. During the next years, in comparison with the 2010 results $^{16}$ Georgia has achieved considerable progress. According to the 2018 survey, Georgia took $60^{\text {th }}$ place in overall E-Government Development Index ${ }^{17}$, this result was largely contributed by the digital services, implemented in the framework of the OGP action plans.

14 For more on Georgian economy, please see: CHARAIA, Vakhtang.; CHOCHIA, Archil.; LASHKHI, Mariam. Caucasus 3 plus Baltic 3 and Economic Cooperation with China. Baltic Journal of European Studies, 2018, vol. 8, no. 2, pp. 44-64.

15 CHOCHIA, Archil \& POPJANEVSKI, Johanna. Change of Power and Its Influence on Country's Europeanization Process. Case Study: Georgia. In: KERIKMÄE, Tanel. CHOCHIA, A. (Eds.). Political and Legal Perspectives of the EU Eastern Partnership Policy, 2016, pp. 197-210. Springer International Publishing.

16 UN E-Government Survey 2010; Online. Available at: https://publicadministration. un.org/egovkb/en-us/Reports/UN-E-Government-Survey-2010; Accessed: 16.09.2019.

17 UN E-Government Survey 2018. Online. Available at: https://publicadministration. un.org/egovkb/en-us/Reports/UN-E-Government-Survey-2018; Accessed: 16.09.2019. 
Alongside with the implementation of innovative services, the shortcomings of the digital system have become vivid. In 2008, there were no relevant legislative frameworks that would have defined cyberspace regulations, therefore, there were no state agencies responsible for maintaining the cybersecurity of the Governmental web-portals. ${ }^{18}$

The cyber-attack carried out during the Russo-Georgian war in 2008 was the first sign for Georgia to improve its cybersecurity potential, in order to maintain national security. 2007-2008 was the beginning of the cyberwarfare era.

Georgia was not the only state which had experienced cyber-attacks against governmental web-portals. In 2007 Estonia became the victim of a massive cyber attack. Due to the nature, of cybercrime, it is impossible to prove that cyberattacks are organized by the rival states, although experts working on cybersecurity issues assume that behind the attack in 2007 stood the Russian government ${ }^{19}$ because it was carried out, after a disputed relocation of the Soviet-era "Bronze Soldier" monument, causing the protest of Russian speaking population. During the attack, fifty-eight Estonian websites went offline at once. On 27 April 2007, hackers attacked newspapers, televisions, banks and official emails of government authorities. It was the first cyber-attack in the world that was linked to a so-called "hybrid war". One year later from "Bronze Soldier" events, during the Russo-Georgian war, a similar type of cyber-attack was carried out against Georgian web-portals.

These facts of massive cyberattacks encouraged western countries to create state policies of cybersecurity. In July 2016, NATO recognised cyberspace as a domain of operations in which NATO must defend itself as effectively as it does in the air, on land and at sea, and therefore the protection of cyberspace has become an issue of the national security for the European states. ${ }^{20}$

\subsection{Cyber incidents in Georgian Cyberspace}

In August 2008 Georgia was the victim of so-called Hybrid warfare. Together with the military power, the country was attacked by the hackers. There were three different targets of the cyber attacks: 1 . government websites, 2 . news agencies' web pages, 3 . internal means of communication. In total, hackers managed to get 100 Georgian web-portals out of order. ${ }^{21}$ Among them were the web pages of the President and the Parliament of Georgia.

18 CHOCHIA, A.; KERIKMÄE, T. Digital Single Market as an Element in EU-Georgian Cooperation. Baltic Journal of European Studies, 2018, vol. 8, no. 2, pp. 3-6.

19 TAMBUR, Silver. How Estonia became a global heavyweight in cyber security, 2017. Online. Available at: http://estonianworld.com/security/estonia-became-global-heavyweight-cyber-security/; Accessed: 16.09.2019.

20 North Atlantic Treaty Organization (NATO). Cyber defence. Online. Retrieved from: https://www.nato.int/cps/en/natohq/topics_78170.htm; Accessed: 20.10.2019

21 LOMIDZE, Irakli. Cyber Attacks Against Georgia. Report for Georgian It Innovations; 
Irakli Gvenetadze, an expert in the cybersecurity field and former head of the Legal Entity of Public Law - Service Agency of the Ministry of Internal Affairs of Georgia (LEPL), ${ }^{22}$ says, that - "attackers tried to achieve several goals, their aim was to cause panic in the population, destroy the digital databases of the governmental platforms and to create an information vacuum. Compared to today's reality, in 2008, Georgia was less dependent on electronic services, hence the cyber attack did not have fatal consequences. Even though certain ministries already had electronic databases, most of the state's bureaucratic operations were conducted still on paper.

As already mentioned, it was the first cyberattack, which was conducted simultaneously with the military intervention, and even though there is no official proof that the Russian government was involved in it, hackers deliberately were trying to act in the interests of Russia, in particular, they spread misinformation to cause the panic in society, they were attacking the English-language news portals, to create information vacuum and prevent Georgian agencies to spread information, thus trying to spread Russian propaganda and to take advantage in the information warfare. It is noteworthy fact, that during the Crimea annexation ${ }^{23}$, the Ukrainian Government became the victim of the same type of Cyberattacks. ${ }^{24}$

In 2008 various methods of cyber-attack were used against Georgia. As a result of DDOS (distributed denial-of-service attack), Georgian web pages were overwhelmed with traffic from multiple sources. This is the method, when hackers are using hundreds, sometimes even thousands of botnets to generate huge floods of traffic and paralyze a target system. ${ }^{25}$ In 2008 , using botnets hackers sent from 300 to 400 unique request to Georgian portals, thus causing server failures.

In addition to the DDOS attack, attackers used the SQL INJECTION method to hack 100 Georgian websites. SQL injection exploits a security vulnerability in an application's software, web pages that result in the weak point of the site. ${ }^{26}$ After getting this information, hackers can easily get into the system. The fact that about 100 Georgian websites were hacked using the mentioned method,

Online; Data exchange agency, 2011; Retrieved from: http://dea.gov.ge/uploads/GITI\%20 2011/GITI2011_3.pdf; Accessed: 15.09.2019.

22 LEPL is a state agency responsible for e-Government establishment in Georgia.

23 VALUCH, Jozef; HAMULÁK, Ondrej. Abuse of cyberspace within the crisis in Ukraine. The Lawyer Quarterly, 2018, vol. 8, no. 2, pp. 94-107.

24 ZINETS, Natalia. Ukraine hit by 6,500 hack attacks, sees Russian 'cyberwar', Reuters. Online, Retrieved from: https://www.reuters.com/article/us-ukraine-crisis-cyber/ukrainehit-by-6500-hack-attacks-sees-russian-cyberwar-idUSKBN14I1QC Accessed: 17.10.2019.

25 MIRKOVIC, Jelena. \& REIHER, Peter. A taxonomy of DDoS attack and DDoS defense mechanisms. ACM SIGCOMM Computer Communication Review, 2004, vol. 34, no. 2, pp. 39-53.

26 BOYD, Stephen, \& KEROMYTIS, Angelos, SQLrand: Preventing SQL injection attacks. In International Conference on Applied Cryptography and Network Security, 2004, pp. 292302. Springer, Berlin, Heidelberg. 
indicates that criminals had started preparing for this operation few months earlier and carried out precisely when the Russian Federation started the military operation against Georgia.

In addition to these methods, hackers used Border Gateway Protocol (BGP hijacking - allows to reroute Internet traffic. Attackers control groups of IP addresses that they do not own $)^{27}$ and tried to control Georgian IP addresses.

This was the first time when large-scale military actions were accompanied by massive cyber attacks. In 2008 there was no coordinated cybersecurity action plan in Georgia, to ensure state policy, consequently, there were no special state agencies responsible for maintaining the security of state cyberspace and not even a relevant criminal law, which allowed to qualify cyber attack as cybercrime, therefore Georgia was not prepared. It is noteworthy, that the Estonian and Polish CERTs (Computer emergency response team) together with the Georgian organization "GRENA" at some extent have managed to reduce the damage of mentioned attack. ${ }^{28}$

In 2013 the website of the Georgian parliament was attacked. The group of Iranian hackers hacked the website of the legislative body and left the following message: "We love Iran. We are not an enemy of any people. Please Patch your web security, because your security is too low, we will not touch your database." - This message was left on December 31, 2013, two weeks later Iranian hackers attacked the website of the Parliament again, but this time they destroyed the database. This cyber attack was not politically motivated, but once again demonstrated that the Georgian Cyberspace was not properly secured.

Cybersecurity is not just prevention of cybercriminal, but it also includes maintaining the proper functioning of web-portals of important state and private organizations. As it was already mentioned, cybersecurity is one of the key pillars of e-governance establishment, therefore, the frequent failures of the governmental web-portals are one of the main hindering factors of this process. This kind of failures reduces citizen's trust toward the digital technologies and electronic services implemented by the government.

In 2014, the governmental web-portal used for children's online registration in kindergartens, operating under the Ministry of Education of Georgia, unexpectedly shut down..$^{29}$ The information about website failure was spread imme-

27 SCHLAMP, Johann. HOLZE, Ralph. JACQUEMART, Quentin. HEAP: reliable assessment of BGP hijacking attacks. IEEE Journal on Selected Areas in Communications, 2016, vol. 34, no. 6, pp. 1849-1861.

28 LEPIK, Toomas \& TABATADZE, David. Estoniana \& Georgian Cyber Attacks. $21^{\text {st }}$ Annual FIRST Conference, Kyoto, June 28 - July 3, 2009. Online, Available at: https://www.first. org/resources/papers/conference2009/lepiktabatadze-sliders.pdf Accessed: 15.10.2019.

29 DADIANI, Natalia. Kindergarten web-portal failure. Online, Retrieved from: https://www. ambebi.ge/article/106265-sabavshvo-bagis-garet-darchenili-bavshvebi-da-gamcarebulimshoblebi-mougvarebeli-problemis-mizezebi-da-shedegebi/ Accessed: 12.11.2019. 
diately by news agencies. Failure was similar to DDoS attack, but it was not an intended cybercrime, the server just turned down because it could not manage the number of visitors. This case didn't cause a big material loss for the state, but it was negatively reflected on public attitudes towards digital services. The negative public attitude towards e-services and lack of trust are one of the main hindering factors of e-governance implementation.

August 2015 - Tbilisi hosted the Super Cup final between Fc "Barcelona" and "Sevilla". Tickets for this match could have been purchased online, on page - "Biletebi.ge", however, since the site server had the limit to respond up to 2000 of unique visitor requests at the same time, and the number of online customers reached almost 100000 , the portal shut down.

May 2015 - a massive DDoS attack was carried out against Georgian financial institutions. Over 300,000 unique IP addresses from more than 160 countries at the same time sent requests on Georgian financial institutions web portals, but this time Georgia was prepared for such a threat and could avoid it. ${ }^{30}$

As a conclusion it can be said, that cybersecurity has a crucial importance in the of E-governance establishment process. Reports of the United Nations E-governance surveys can be indicator of the influence of cybersecurity on the E-governance establishment process. In the Graph 1, will be provided results of Georgia according to the UN's E-governance survey for the last 18 years and it can be seen, how 2008 cyberattack influenced on Georgia's e-governance ranking.

\section{Graph 1 - Index of Georgian E-government and its components development;}

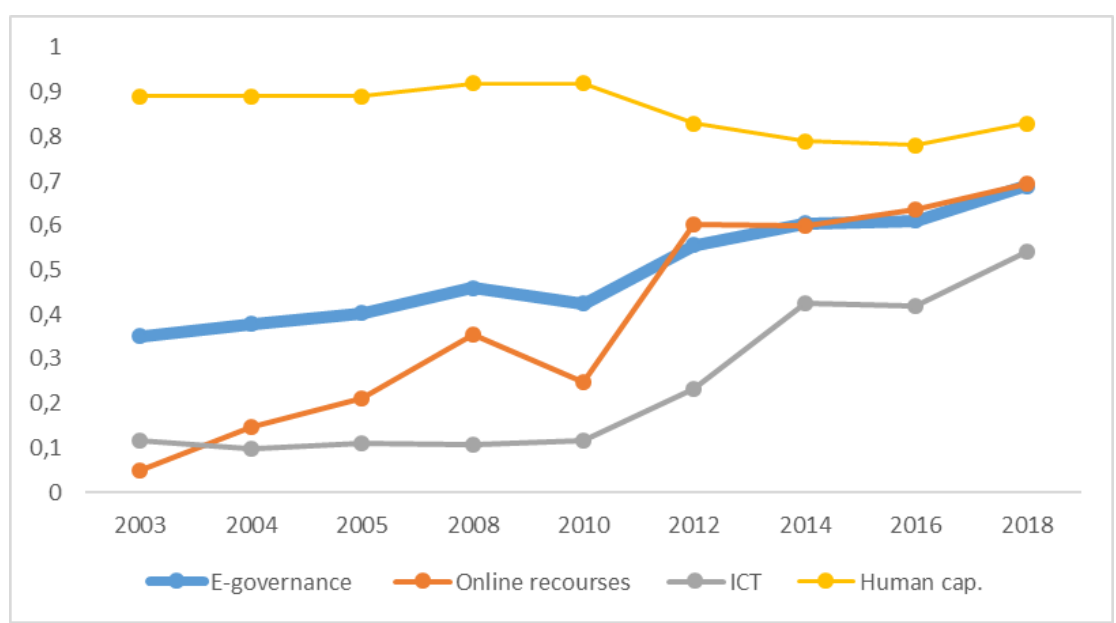

30 SVANADZE, Vladimer. Akhali gamotsveva saqartvelos internet sivrcistvis [sbsmo

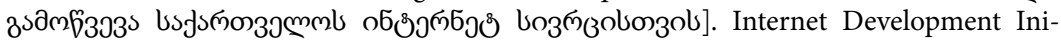
tiative - IDI, 2015. Retrieved from: http://indein.net/wp-content/uploads/2015/09/NewChallenges-for-Georgian-Cyber-Space.pdf; Accessed: 15.09.2019. 
According to the survey, E-governance index (Blue line) is measured by the combination of 3 components: online recourses (purple line); ICT infrastructure (grey line) and human capital index (yellow line); In the given diagram is provided information about development of each mentioned components during the last 15 years. Each component affects e-governance general index, as it can be seen, according to UN E-governance Survey 2010 report, index of online recourses has decreased dramatically, which had influenced E-governance index development. The fact that in August 2008 Georgia couldn't prevent massive cyber-attack against government web-portals, influenced its online recourses index, thus causing a fall in global e-governance rankings.

\subsection{Implementation of a Cybersecurity state policy}

The cyber-attack against Georgia in 2008 clearly demonstrated shortcomings of Georgian cybersecurity policy. There was no relevant legislation, nor strategy that would have ensured the country's defense capability against new cyber challenges.

In 2010, the government adopted the "Threat Assessment Document of Georgia 2010-2013", ${ }^{31}$ in which the protection of cyberspace was declared as an issue of national security of Georgia: "During the August 2008 War the Russian Federation used concentrated and massive cyber attacks against Georgia in parallel with the use of ground, air, and naval forces. These cyber attacks demonstrated that defense of cyber space is as important for national security as defense of land, sea, and aerial spaces. The experience of 2008 shows that attacks employing information technologies present a realistic threat in the modern globalized world," - the document reads.

In 2010 as a part of CRIMINAL CODE OF GEORGIA, the government adopted - Cybercrime Law of Georgia After defining the cybersecurity as one of the main aspects of national security, the government of Georgia elaborated additional documents serving to improve cybersecurity capabilities. After the ratification of European Council's Cybersecurity Convention in 2012, Georgia has officially joined a list of countries that have had officially declared war to cybercrime.

On the one hand, to create the effective cybersecurity environment, the state needed relevant legislation, in a framework of which new action plans and strategies would have been adopted, and on another hand, based on cybersecurity action plans, the government could establish relevant agencies, responsible for maintaining the state cybersecurity.

31 Ministry of Defence of Georgia. Threat Assessment Document for 2010-2013. Retrieved from: https://mod.gov.ge/uploads/2018/pdf/TAD-ENG.pdf Accessed: 02.10.2019. 
On June 5, 2012, the President of Georgia signed the "Law on Information Security" 32 (Table 1), which entered into force on July 1 of the same year. The law consists of 4 chapters and 12 articles, defining the state's cybersecurity policy:

Table 1. "Law on Information Security"

\begin{tabular}{|c|c|}
\hline \multirow{3}{*}{$\begin{array}{c}\text { Chapter } \\
\text { I - “General } \\
\text { Provisions" }\end{array}$} & Article 1 - "Purpose of the Law"; \\
\hline & Article 2 - "Definition of terms"; \\
\hline & Article 3 - "Scope of the Law; \\
\hline \multirow{4}{*}{$\begin{array}{c}\text { Chapter II - } \\
\text { "Organisation } \\
\text { and Provision } \\
\text { of Informa- } \\
\text { tion Security" }\end{array}$} & Article 4-Rules for information security; \\
\hline & Article 5 - Information Asset Management; \\
\hline & $\begin{array}{l}\text { Article } 6 \text { - Information security audit and } \\
\text { information systems testing; }\end{array}$ \\
\hline & Article 7 - Information security manager; \\
\hline \multirow{6}{*}{$\begin{array}{c}\text { Chapter III } \\
\text { - Ensuring } \\
\text { Cybersecurity } \\
+ \text { Chapter III-1 } \\
\text { - Cybersecu- } \\
\text { rity Bureau } \\
\text { (24 Decem- } \\
\text { ber 2013) }\end{array}$} & $\begin{array}{l}\text { Article } 8 \text { - Computer Emergency Response } \\
\text { Team of the Data Exchange Agency; }\end{array}$ \\
\hline & Article 9 - Cybersecurity specialist; \\
\hline & Article 10 - Computer incident identification; \\
\hline & Article 10.1 - Status and functions of the Cybersecurity Bureau; \\
\hline & Article 10.2 - Director of the Cybersecurity Bureau; \\
\hline & Article 10.3 - CERT of the Cybersecurity Bureau; \\
\hline \multirow{2}{*}{\begin{tabular}{|c|} 
Chapter IV \\
- Transition- \\
al and Final \\
Provisions \\
\end{tabular}} & Article 11 - Transitional provisions; \\
\hline & Article 12 - Final provision. \\
\hline
\end{tabular}

According to Chapter IV within 6 months after the law came into the force, the President of Georgia had to pass a decree on "The list of critical information system subjects", as well as the order about the creation of "the computer emergency response team" (CERT).

In addition, according to the law, the Ministry of Defense of Georgia was ordered to create a state body responsible for state cybersecurity - "Cybersecurity Bureau" until 1 April 2014.

This law has created legal basis for the development of the state cybersecurity. The state bodies responsible for this process have been identified and elaboration of the Cybersecurity Action Plan became part of the Georgian political agenda.

On 11 March 2013, in accordance with the Law of Georgia on "Information Security", the President approved the list of critical information system subjects. ${ }^{33}$ In total, 36 objects were identified, and the CERT of the Data Exchange

32 Act of 05.06.2012. Law on Information Security of Georgia. Available at: https://matsne. gov.ge/en/document/view/1679424?publication=3 Accessed: 11.10.2019

33 Please see the list of critical information system subjects at https://matsne.gov.ge/ka/document/view/1867646 
Agency was responsible to provide Cybersecurity services to these subjects. On April 29, 2014, the Government of Georgia added 3 objects to the existing list. ${ }^{34}$

\subsection{Cybersecurity Strategy of Georgia and Action Plans for the Cybersecurity Strategy}

On 17th of May 2013, the President of Georgia signed "Cybersecurity Strategy of Georgia and Action Plan for the Cybersecurity Strategy of Georgia 2012$2015{ }^{\prime 35}$

On 17th of January 2017, the Government of Georgia approved the second action plan of the state Cybersecurity. Both documents consisted of 5 directions, defining cybersecurity policy and responsible state agencies. ${ }^{36}$

First goal - Research and analysis: This was the first goal of the both action plans. Comparing to previous document, the first chapter of the action plan 2017-18 consists of 5 sub-pillars. Difference between the goals of mentioned documents can be clearly seen in the table 2 .

Table 2. Comparison the first chapters of the cybersecurity state strategy documents

\begin{tabular}{|c|c|}
\hline $\begin{array}{c}\text { 2012-15 Doc. } \\
\begin{array}{c}\text { Study of other states' best prac- } \\
\text { tices and sharing experience; }\end{array}\end{array}$ & $\begin{array}{c}\text { 2017-18 Doc. } \\
\text { Development of standards deter- } \\
\text { mining the cybersecurity with the } \\
\text { objective to implement them later; }\end{array}$ \\
\hline $\begin{array}{c}\text { Research the criteria and stand- } \\
\text { ards to identify objects of criti- } \\
\text { cal information systems; }\end{array}$ & $\begin{array}{c}\text { Research of identification crite- } \\
\text { ria and standards for the critical } \\
\text { informational infrastructure; }\end{array}$ \\
\hline $\begin{array}{c}\text { Resilience analysis of criti- } \\
\text { cal information systems; }\end{array}$ & $\begin{array}{c}\text { Analysis of sustainability of criti- } \\
\text { cal informational infrastructure; }\end{array}$ \\
\hline $\begin{array}{c}\text { Analysis of the problems in the region } \\
\text { regarding the cybersecurity }\end{array}$ & $\begin{array}{c}\text { Study of issues existing in the area } \\
\text { of cybersecurity in the region; }\end{array}$ \\
\hline- & $\begin{array}{c}\text { Periodic drafting of proposals related } \\
\text { to the identification of threats and risks } \\
\text { faced by the Georgian cyber field; }\end{array}$ \\
\hline
\end{tabular}

34 Please see list of critical information system subjects at https://matsne.gov.ge/ka/document/view/2333175

35 Please see Cybersecurity Strategy of Georgia and Action Plan for the Cybersecurity Strategy of Georgia 2012-2015 at https://matsne.gov.ge/ka/document/view/1923932

36 Please see the Cybersecurity Strategy of Georgia and Action Plan for the Cybersecurity Strategy of Georgia 2017-2018 at http://gov.ge/files/469_59439_212523_14.pdf 
The second chapters (Table 3) of the documents considers improving the legislation framework regarding cybersecurity issues:

Table 3. Comparison the second chapters of the cybersecurity state strategy documents

\begin{tabular}{|c|c|}
\hline $\begin{array}{l}2012-15 \text { Doc. } \\
\text { II - Introduction of legislative } \\
\text { acts on information security; }\end{array}$ & $\begin{array}{l}2017-18 \text { Doc. } \\
\text { II - updating of legal base pro- } \\
\text { viding the cybersecurity of } \\
\text { the information systems; }\end{array}$ \\
\hline $\begin{array}{l}\text { Development of the regulatory frame- } \\
\text { work to identify the critical infor- } \\
\text { mation systems and actions neces- } \\
\text { sary for ensuring cybersecurity; }\end{array}$ & $\begin{array}{l}\text { Creation of normative base defining } \\
\text { the critical informational infrastruc- } \\
\text { ture and ensuring the cybersecurity; }\end{array}$ \\
\hline $\begin{array}{l}\text { Introduction of the legal basis } \\
\text { for Computer Emergency } \\
\text { Response Team operations; }\end{array}$ & $\begin{array}{l}\text { Development of mechanisms } \\
\text { for the execution of obligations } \\
\text { defined under the legislation; }\end{array}$ \\
\hline $\begin{array}{l}\text { Ratification of the } 2001 \text { Coun- } \\
\text { cil of Europe Convention } \\
\text { Against Cybercrime; }\end{array}$ & $\begin{array}{l}\text { Continuation of fulfilment of obliga- } \\
\text { tions undertaken as a result of ratifica- } \\
\text { tion of the } 2001 \text { Council of Europe } \\
\text { Convention "On Cybercrime"; }\end{array}$ \\
\hline $\begin{array}{l}\text { Development of the contingency } \\
\text { plans and recovery procedures. }\end{array}$ & $\begin{array}{l}\text { Processing of scenarios of alleged } \\
\text { development of cyber-incidents-related } \\
\text { events and specifying of backup } \\
\text { plans and procedures for relevant } \\
\text { actions, during emergency, military } \\
\text { and other type of crisis situations }\end{array}$ \\
\hline $\begin{array}{l}\text { Legal identification of an agency or } \\
\text { agencies responsible for designation } \\
\text { of information security policies and } \\
\text { undertaking coordinating functions }\end{array}$ & $\begin{array}{l}\text { Improving the mechanisms of } \\
\text { cooperation with suppliers of criti- } \\
\text { cal information systems; }\end{array}$ \\
\hline
\end{tabular}

The third chapter (Table 4) of the cybersecurity strategies concerns institutional coordination between governmental bodies to ensure proper functioning of cybersecurity infrastructure. 
ICLR, 2019, Vol. 19, No. 2.

Table 4. Comparison the third chapters of the cybersecurity state strategy documents

\begin{tabular}{|c|c|}
\hline $\begin{array}{c}\text { 2012-15 Doc. } \\
\text { III-Institutional coordination } \\
\text { for ensuring cybersecurity }\end{array}$ & $\begin{array}{c}\text { 2017-18 Doc. } \\
\text { in - Strengthening Capabilities }\end{array}$ \\
\hline $\begin{array}{c}\text { Further development of the Com- } \\
\text { puter Emergency Response Team; }\end{array}$ & $\begin{array}{c}\text { Further development of capa- } \\
\text { bilities of computer incidents } \\
\text { fast response group; }\end{array}$ \\
\hline $\begin{array}{c}\text { Designation of the expert support } \\
\text { team/unit in cybercrime cases; }\end{array}$ & $\begin{array}{c}\text { Further development of opportunities of } \\
\text { expertise research of computer data; }\end{array}$ \\
\hline $\begin{array}{c}\text { Establishment of the 24/7 high-tech } \\
\text { crime (cybercrime) international } \\
\text { contact point as required by the 2001 } \\
\text { Convention against Cybercrime; }\end{array}$ & $\begin{array}{c}\text { Creation and development of encrypted } \\
\text { system of exchange of informa- } \\
\text { tion containing the state secret; }\end{array}$ \\
\hline $\begin{array}{c}\text { Establishment of the format and modali- } \\
\text { ties for public-private cooperation. }\end{array}$ & $\begin{array}{c}\text { Carrying out the trainings and cyber- } \\
\text { exercises adjusted to the situational sce- } \\
\text { narios based on cybersecurity incidents; }\end{array}$ \\
\hline
\end{tabular}

In the both strategies, the fourth direction involves public awareness raising and the establishment if the educational base (Table 5).

Table 5. Comparison the fourth chapters of the cybersecurity state strategy documents

\begin{tabular}{|c|c|}
\hline $\begin{array}{l}\text { 2012-15 Doc. } \\
\text { IV - Public awareness and education }\end{array}$ & $\begin{array}{l}\text { 2017-18 Doc. } \\
\text { IV - Public awareness raising and } \\
\text { establishment of educational base }\end{array}$ \\
\hline $\begin{array}{l}\text { Establishment of the public } \\
\text { awareness and educational pro- } \\
\text { grams on cybersecurity; }\end{array}$ & $\begin{array}{l}\text { Creation of educational and pub- } \\
\text { lic awareness raising programs } \\
\text { in the field of cybersecurity; }\end{array}$ \\
\hline $\begin{array}{l}\text { Training of the staff and technical per- } \\
\text { sonnel of the critical information system } \\
\text { subjects and other interested organiza- } \\
\text { tions in order to learn international and } \\
\text { local standards of information security; }\end{array}$ & $\begin{array}{l}\text { Training of staff and technical person- } \\
\text { nel of critical information infrastruc- } \\
\text { ture bodies and other interested organi- } \\
\text { zations, with the objective of studying } \\
\text { international and national standards } \\
\text { in the field of informational security; }\end{array}$ \\
\hline $\begin{array}{l}\text { Training of the specialized cybercrime } \\
\text { experts in the area of handling elec- } \\
\text { tronic evidence (cyber forensics); }\end{array}$ & $\begin{array}{l}\text { Capacity building of higher educa- } \\
\text { tion system in the fields of cyber } \\
\text { and information security; }\end{array}$ \\
\hline
\end{tabular}




\begin{tabular}{|c|c|}
\hline $\begin{array}{c}\text { Support the science and research } \\
\text { projects in cybersecurity; }\end{array}$ & $\begin{array}{c}\text { Facilitation of scientific research } \\
\text { projects in the field of cybersecurity; }\end{array}$ \\
\hline Creation of the research lab. & $\begin{array}{c}\text { Specialized trainings in investigation } \\
\text { of cyber-incidents directed against } \\
\text { the Georgian national security; }\end{array}$ \\
\hline
\end{tabular}

In the 2017-18 action plan (Table 6), the Fifth goal - "the international cooperation in cybersecurity field" is a copy of the same chapter from the action plan 2012-15, except one new aspect: "Creation and development of a regional centre for cybersecurity research and study."

Table 6. Comparison the fifth chapters of the cybersecurity state strategy documents

\begin{tabular}{|c|c|}
\hline $\begin{array}{l}\text { 2012-15 Doc. } \\
\text { V - the international coopera- } \\
\text { tion in cybersecurity field }\end{array}$ & $\begin{array}{l}\text { 2017-18 Doc. } \\
\text { V - the international coopera- } \\
\text { tion in cybersecurity field }\end{array}$ \\
\hline $\begin{array}{l}\text { Strengthening relations on cybersecu- } \\
\text { rity issues with international organiza- } \\
\text { tions (OECD, EU, OSCE, NATO, UN, } \\
\text { ITU) working in cybersecurity field as } \\
\text { well as relevant national authorities; }\end{array}$ & $\begin{array}{l}\text { Strengthening of international } \\
\text { relations on cybersecurity issues } \\
\text { with the international organiza- } \\
\text { tions (OECD, EU, OSCE, NATO, } \\
\text { CoE, UN, ITU and others) and } \\
\text { state bodies working in this field; }\end{array}$ \\
\hline $\begin{array}{l}\text { Active participation in interna- } \\
\text { tional activities related to cyberse- } \\
\text { curity and support of the relevant } \\
\text { initiatives on a regional scale; }\end{array}$ & $\begin{array}{l}\text { Active participation in the inter- } \\
\text { national initiatives in the field of } \\
\text { cybersecurity and support to these } \\
\text { initiatives at the regional level; }\end{array}$ \\
\hline $\begin{array}{l}\text { Initiating bilateral and multilat- } \\
\text { eral cooperation with national } \\
\text { CERTs in the area of cybersecurity. }\end{array}$ & $\begin{array}{l}\text { Initiation of cooperation with } \\
\text { CERTs of other countries in the } \\
\text { field of cybersecurity under bilat- } \\
\text { eral and multilateral formats; }\end{array}$ \\
\hline - & $\begin{array}{l}\text { Creation and development of } \\
\text { a regional centre for cyberse- } \\
\text { curity research and study. }\end{array}$ \\
\hline
\end{tabular}

In total, up to 20 state agencies were involved in implementing cybersecurity strategy and action plans, documents which defined Georgia's cybersecurity policy and thus greatly contributed to the protection of Georgian cyberspace. 


\subsection{State agencies responsible for Cyber Security}

In 2008, when the large-scale cyber-attack was carried out against Georgia, there was no state agency responsible for cybersecurity of the country. Consequently, it became clear that various ministries and their subordinate administrations had to be established in order to respond to cyber threats. Today there are 3 State agencies responsible for cyber security of Georgia.

On $11^{\text {th }}$ of January 2011, under the Data Exchange Agency of the Ministry of Justice of Georgia - CERT (Computer emergency response team) started to operate. It is an agency, responsible for handling critical incidents that occur within Georgian Governmental Networks and critical infrastructure.

On $28^{\text {th }}$ of January 2014, under the Ministry of Defence of Georgia the Cyber Security Bureau was established. The aim of Cyber Security Bureau is to develop stable, effective and secure Information and Communication Technology systems for the Civil Office of MoD of Georgia, structural sub-divisions of Military Forces of General Staff and LEPLs under MoD.

Main goals of Cyber Security Bureau:

- "Development of Cyber Security joint policy;

- Provision of information and communication technology system security in Defence sector;

- Implementation, operationalization and development of computer security incident response 24/7 mechanisms (CSIRT, CSIRT/CC, Call Center 24/7);

- Protection of information and communication technology infrastructure under the MOD of Georgia from cyber threats and cyber risks;

- Study existing infrastructure within the MOD of Georgia, development and enhancement of its security;

- Harmonization of Georgian Legislation with international legal norms;

- Provision of awareness building in Cyber Security field;

- Participation in educational programs and trainings;

- $\quad$ Establishing close relations on national and international level;

- Retraining military personnel according to the contemporary standards of cyber security." 37

The above-mentioned agencies are responsible for cyber security of 39 key infrastructure facilities combined. Cyber Security Bureau is responsible for the security of only 5 key information objects, while Data Exchange Agency and CERT are responsible for all the other objects.

The activities of the above-mentioned bodies are aimed to fight cyber-attacks addressed against Georgian public organizations, although in Georgia operates

37 Ministry of Defence of Georgia. Cyber Security Bureau. Retrieved from: https://mod.gov. ge/en/page/59/cyber-security-bureau Accessed: 02.10.2019 
the agency, which responses to cyber-crime against natural persons. In December 2012 Special Cybercrime Unit was established within the Central Criminal Police Department, Ministry of Internal Affairs of Georgia (MIA). This Unit is responsible for detection, "suppression and prevention of illegal activities committed in cyberspace“

Moreover, Special Subunit for Computer-Digital Forensics was created within system of MIA Forensics-Criminalistics Main Division that carries out functions of first handling and further forensics of digital evidences." ${ }^{38}$

\subsection{Georgia in the Cybersecurity global index research}

In the framework of the given article, there were discussed the institutional reforms, which had a great influence on country's cybersecurity capabilities, which was reflected in the rankings of international cybersecurity researches.

In 2017, Georgia was placed in the list of the top 10 countries with the best cybersecurity environment.

International Telecommunication Union - ITU, which operates under the UN, published results of the international research - „Global Cybersecurity Index 2017” - which included results of 193 states. It is noteworthy that among the mentioned states, Georgia took $8^{\text {th }}$ place. ${ }^{39}$

Study combined 5 main pillars, which united 25 components. The main directions of the research were: legal; technical; organizational; capacity building; cooperation pillars.

Legal pillar included 3 components: Cybercriminal legislation, cybersecurity regulation, Cybersecurity training (Out of maximum 1 point, Georgia got - 0.91);

Technical pillar was divided into 6 components: National CIRT; Government CIRT; Sectoral CIRT; Standards for Organizations; Standards and certification for professionals; Child online protection (Georgia - 0.77);

Organizational pillar with 3 components: Strategy, Responsible agency, cybersecurity metrics (Georgia - 0.82);

Capacity building pillar united following components: - Standardization bodies; Good practices Research and Development programmers, Public awareness campaigns, Professional training courses, National education programmers

38 Ministry of Internal Affairs of Georgia. Actions carried out by the ministry of internal affairs of Georgia. Retrieved from: https://police.ge/en/projects/kiberdanashauli/shinagan-saqmeta-saministros-mier-gankhortsielebuli-ghonisdziebebi Accessed: 02.10.2019

39 International Telecommunication Union. Global Cybersecurity Index (GCI) 2017. Online; Available at: https://www.itu.int/dms_pub/itu-d/opb/str/D-STR-GCI.01-2017-PDF-E.pdf; Accessed: 15.09.2019. 
and academic curricula; Incentive mechanisms; Home-grown cybersecurity industry (Georgia - 0.90);

Cooperation pillar: Intra-state cooperation, Multilateral agreements, International fora participation, Public-private partnerships, Inter-agency partnerships (Georgia - 0.70);

In total, the main 5 pillars of the research included 25 components, which were evaluated using 157 questions. International Telecommunication Union sent these questions to the field experts to evaluate the state of cybersecurity in the country. According to the assessments, with 0.81 points Georgia took 8th place in the global ranking of Cybersecurity index.

According to the results, the weakest aspects of the Georgian cybersecurity are technical and cooperation pillars. It is noteworthy, in 2019 ITU has published another research of cybersecurity index, with re-evaluated and modified weighting values. The number of questions has been reduced from 153 to 50 and questions have been merged into clearer and more comprehensive forms. For research and data collection, in order to complete the survey, official sources were used. As a result, with the score 0.857 , Georgia took $9^{\text {th }}$ place in the regional rank (Overtaking such countries as Germany, Finland, Denmark, Italy, Austria e.tc.) and $18^{\text {th }}$ place in the Global rank. ${ }^{40}$

Another important document about global cybersecurity index is - "NCSINational Cyber Security Index", conducted by the Estonian e-Governance Academy, in 2018, the study, which measures the preparedness of countries against cyber threats and cyber incidents. ${ }^{41}$ The study is focused on measurable aspects of cybersecurity. The scope of the research covers:

- Legislation pillar- legal acts, regulations, official orders, etc.

- Organizational pillar - Established units: existing organizations, departments, CERT.

- Cooperation formats - council, committee, official working group, etc.

- Outcomes / Products - policies, exercises, technologies, websites, programs, etc.

In the framework of the study, 12 capacities of each country are evaluated according to the 46 indicators.

40 International Telecommunication Union. Global Cybersecurity Index (GCI) 2018. Online. Available at https://www.itu.int/dms_pub/itu-d/opb/str/D-STR-GCI.01-2018-PDF-E.pdf; Accessed: 15.09.2019

41 E-Governance Academy. NCSI-National Cyber Security Index, 2018. Online; Available at: https://ega.ee/wp-content/uploads/2018/05/ncsi_digital_smaller.pdf; Accessed: 15.09.2019. 
Table 7. Georgia in Cybersecurity global index survey of E-Gov. academy

19. 歫 Georgia

Population

3.7 million

Area $\left(\mathrm{km}^{2}\right)$

69.7 thousand

GDP per capita (\$)

10.6 thousand

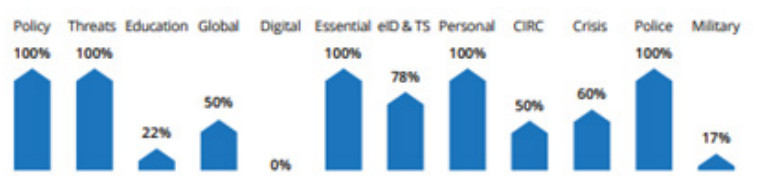

As a result of the research, with the point 64.9 , Georgia took $19^{\text {th }}$ place in the ranking of Global cybersecurity index (Table 7), conducted by the E-governance academy.

1. E-identification and trust services - eID \& TS - $78 \%$

- No Requirements for cryptosystems in the field of trust services are regulated.)

2. Protection of personal data - personal - $100 \%$;

3. Cyber incidents response $24 / 7$ - CIRC - 50\%;

- There is no legal act, according to which digital service providers and operators of essential services have an obligation to notify appointed government authorities of cyber security incidents;

- There is no single point of contact for international cyber security coordination;

4. Cyber crisis management - Crisis $-60 \%$;

- There is no established crisis management plan for large-scale cyber incidents;

- There are no procedures for using volunteers in the field of cyber security;

5. Fight against cybercrime - Police $-\mathbf{1 0 0 \%}$;

6. Military cyber operations - Military $-17 \%$;

- Military forces have a unit (cyber command, etc.) that is specialised in planning and conducting cyber operations;

- Military forces have conducted a cyber operations exercise or an exercise with a cyber operations component in the country in the last 3 years;

7. Cyber security policy development - Policy $-\mathbf{1 0 0 \%}$;

8. Cyber threats analysis and informing - Threats $-\mathbf{1 0 0 \%}$;

9. Education and professional development - Education - 22\%;

- Primary or secondary education curricula include cyber safety / computer safety competences;

- No Bachelor's, Master's, PhD level cyber security programs;

10. Contribution to global cyber security - Global - 50\%;

- No regional nor international cyber security organisation is hosted by the country; 
11. Protection of digital services - Digital - $\mathbf{0 \%}$;

- There is no legislation, according to which digital service providers or Public sector digital service providers (1) must manage cyber/ ICT risks or (2) must implement established cyber/information security requirements;

- No supervisor to public and private digital service providers regarding the implementation of cyber/information security requirements;

12. Protection of essential services - Essential - 100\%;

Despite the various methodologies, used by ITU and E-governance Academy, rankings of Georgia in the both surveys are very similar. According to the ITU Global Cybersecurity Index 2018, Georgia took $18^{\text {th }}$ place in the global ranking, and according to the E-governance academy's survey, Georgia took $19^{\text {th }}$ place. Both studies are focused on the measurable part of the countries cybersecurity policies. Therefore, they define the strengths and weaknesses of the state cyber policy. Therefore, in the framework of the given article, according to the result of the mentioned surveys, the flaws of the Georgian National Cybersecurity Strategies will be defined and analysed using the tool elaborated by the European Union Agency for Cybersecurity (ENISA), which was created to help States evaluate their strategic priorities and objectives related to National Cyber Security Strategies.

Combining the results of the mentioned studies we get the following outcome: according to the cybersecurity global index researches, Georgian cybersecurity policy has a several flaws:

- $\quad$ Lack of communication between public and private sectors;

- Lack of forums and events with international significance held in Georgia;

- Lack of specific educational curricula and programs;

- Absence of crisis management plan;

- $\quad$ Absence of specialized military units;

- Absence of coordinated single point for international communication.

On the next stag, in the framework of the given article, abovementioned problems of the Georgian cyber security, will be analysed by the "National Cybersecurity Strategies Evaluation Tool" created by ENISA (European Union Agency for Cybersecurity). This tool was created to help States evaluate their strategic priorities and objectives related to National Cyber Security Strategies.

The questionnaire is sectioned in 15 objectives and unites 125 questions and users can define which topic to choose for evaluation. In the given article, according to the Georgian cybersecurity characteristics, the following topics will be used to evaluate Georgian national strategies:

- Develop national cyber contingency plans 
- Raise user awareness

- Strengthen training and educational programmes

- Engage in international cooperation (not only with EU MS)

- Establish a public-private partnership (PPPs)

- Institutionalise cooperation between public agencies ${ }^{42}$

\section{Conclusion}

Georgia is one of the first countries, which has become a victim of organized hybrid warfare. In 2008, during the Russo-Georgian war, the military invasion was accompanied by organized cyber-attacks on Georgian web portals. A decade ago, the country had no elaborated policy of E-governance establishment, nor cybersecurity strategies and action plans. 2008 cyberattack made it clear that defence of the State cybersecurity was as important as defence of an Air, Land and Sea spaces, and it was reflected in the 2010-2013 Risk Assessment Document of Georgia.

In 2012, Georgia ratified the Council of Europe's cyber security convention and adopted the "Law on Information Security" that became a real basis for the implementation of state cybersecurity policy.

In the following years the government started to implement action plans and to define state agencies responsible for cybersecurity policy. As an outcome of these reforms, in 2017, according to Cyber Security Survey conducted by ITU, Georgia was ranked among the top ten countries with the highest cybersecurity index. In 2018, in the global ranking of the cybersecurity index, Georgia was among the best 20 countries, according to the two independent studies conducted by different organizations - E-governance academy Estonia (19th place) and ITU (18th place). Both studies underlined the shortcomings of the Georgian cybersecurity policy. As the next stage, in the framework of the given article, the "National Cybersecurity Strategies Evaluation Tool" was used to evaluate the abovementioned shortcomings of Georgian cybersecurity policy and to elaborate recommendations based on them.

ENISA recommendations:

\section{- Develop national cyber contingency plans}

A cyber-crisis management plan at a national level is a very important element in a national cybersecurity strategy, as it focuses on the national coordination and mitigation efforts during the crisis. Many cyber-incidents occur on a daily basis and are mitigated promptly at an operational level, without nec-

42 European Union Agency for Cybersecurity (ENISA). National Cybersecurity Strategies Evaluation Tool. Available at: https://www.enisa.europa.eu/topics/national-cyber-security-strategies/national-cyber-security-strategies-guidelines-tools/national-cyber-securitystrategies-evaluation-tool Accessed: 10.11.2019. 
essarily leading to a crisis situation. Cyber-crisis specific procedures should explain the steps and actions which are needed during the cyber-crisis. Examples include: coordination of the crisis response; information management; actions related to public affairs; crisis mitigation and separate steps of detecting, analysing, responding, resolving, and terminating the crisis.

\section{- Raise user awareness and strengthen training and educational pro- grammes}

Raising awareness about cyber security threats and vulnerabilities and their impact on society has become vital. Through awareness raising, individual and corporate users can learn how to behave in the online world and protect themselves from typical risks. A mechanism for reaching out the target areas for awareness raising (e.g. citizens, children, end-users) is valuable. The ENISA Threat Landscape (ETL) provides an overview of threats, together with current and emerging trends. To promote and encourage the relations between information security academic environments and the industry, adding information security courses to university curricula - not only to the ones related with computer science but also to any other professional speciality tailored to the needs of that profession is an important task to achieve this objective. To strengthen training and educational programmes, engage in dialogue with universities and other educational institutions to develop new cybersecurity programs or adapt existing ones to the needs of the private/and or public sector. Funding and encouraging specific training courses in cybersecurity focused and delivered at member-state employment agencies and civil servants could help achieve this objective. To align cybersecurity training with business needs, supporting the security accreditation and certification of skilled personnel in key working posts both in public and private sector could help achieve this objective.

\section{- Engage in international cooperation}

Engaging in cooperation and information sharing with partners abroad is important to better understand and respond to a constantly changing threat environment. The use of an international engagement strategy could be considered as an instrument for fostering international cooperation. A strategy can indicate the Member State's stance towards international cooperation.

\section{- Establish a public-private partnership (PPPs)}

A common strategic objective of every European national cyber security strategy is collaboration to enhance cyber security across all levels. The collaboration is often achieved through Public Private Partnerships (PPPs). In the majority of countries, private companies own critical infrastructure and critical services are provided by the private sector. Therefore, a high degree of communication and cooperation can be an effective way for governments to understand the needs and challenges of private companies, but also to ensure that the necessary measures are implemented to achieve a sufficient degree of security. The provision of a 
national action plan is the capstone of establishing a PPP. A national action plan contains near-term actions and puts in place a long-term strategy to enhance cybersecurity awareness, maintain economic and national security, and empowers potential participants to take better control of their digital security.

\section{- Institutionalise cooperation between public agencies}

PPP is about private-private, public-public and private-public cooperation. Focusing only on the relationships between public and private sector could be very short-sighted for the PPP policy. The right level of dialog and understanding between public agencies is often the key

to successful PPP. The same applies to the private sector. The successful PPP integrates not only private administration and the industry, but also different entities among the industry (e.g. energy companies, banks, telecoms). For this reason, the PPPs all over the EU should focus also on private-private and publicpublic cooperation and collaboration.

Cybersecurity global index surveys, such as ITU or E-gov academy researches are a good indicator to assess the development of the state cybersecurity system. The research is mainly based on questionnaires filled by local experts, which evaluates the following issues: the legal framework of the Cyber Security, the structure of government agencies responsible for cybersecurity, government cybersecurity policies, action plans etc.

In 2008 Georgia became the victim of hybrid warfare. 10 years ago, the country had no state policy of cybersecurity, nor a governmental agency responsible for this field, therefore, the country was vulnerable against any kind of cyberattack, but today according to the international studies, Georgia is one of the leading states in regards of cybersecurity. As an outcome of the article, systematized information about Georgian cybersecurity development is offered in Table 7.

Another question is, if this type of researches is valid indicator for the states' cybersecurity potential/capabilities, because results of this kind of international researches are mainly based only on an evaluation of state cybersecurity policy legislation framework and structures. These researches are mainly based on the measurable aspects of cybersecurity, such as Cyber Security legislation, the structure of government agencies responsible for cybersecurity, government cybersecurity policies, action plans, etc, therefore, they might not reflect the objective reality.

According to the mentioned studies, Georgia has one of the best cybersecurity systems worldwide, but on 28 October 2019 , a massive cyber-attack against Georgia has taken place.

Thousands of websites including: two Georgian TV broadcasters, Imedi TV and Maestro, personal, business, and local newspaper sites, along with govern- 
ment sites such as those of the general jurisdiction courts, and Georgian President were temporarily taken offline as well.

\section{References}

AMORETTI, Francesco. ICTs Policies: E-Democracy and E-Government for Political Development, 2007.

BEBBER, Robert "Jake". Cyber power and cyber effectiveness: An analytic framework. Comparative Strategy, 2017, vol. 36, no. 5, pp. 426-436.

BOYD, Stephen, \& KEROMYTIS, Angelos, SQLrand: Preventing SQL injection attacks. In International Conference on Applied Cryptography and Network Security, 2004, pp. 292-302. Springer, Berlin, Heidelberg.

CARR, Madeline. Public-private partnerships in national cyber-security strategies. International Affairs, 2016, vol. 92, no. 1, pp. 43-62.

CHEE-WOOI, Ten. CHEN-CHING, Liu. GOVINDARSU, Manimaran. Vulnerability assessment of cybersecurity for SCADA systems. IEEE Transactions on Power Systems, 2008, vol. 23, no. 4, pp. 1836-1846.

CHOCHIA, Archil \& POPJANEVSKI, Johanna. Change of Power and Its Influence on Country's Europeanization Process. Case Study: Georgia. In: KERIKMÄE, Tanel. CHOCHIA, A. (Eds.). Political and Legal Perspectives of the EU Eastern Partnership Policy, Cham: Springer, 2016, pp. 197-210.

CHOCHIA, Archil \& KERIKMÄE, Tanel. Digital Single Market as an Element in EUGeorgian Cooperation. Baltic Journal of European Studies, 2018, vol. 8, no. 2, pp. 3-6.

CHARAIA, Vakhtang, CHOCHIA, Archil, LASHKHI, Mariam. Caucasus 3 plus Baltic 3 and Economic Cooperation with China. Baltic Journal of European Studies, 2018, vol. 8, no. 2, pp. 44-64.

DE BRUIJN, Hans \& JANSSEN, Marijn. Building cybersecurity awareness: The need for evidence-based framing strategies. Government Information Quarterly, 2017, vol. 34, no. 1, pp. 1-7.

DADIANI, Natalia. Kindergarten web-portal failure. Online, Retrieved from: https:// www.ambebi.ge/article/106265-sabavshvo-bagis-garet-darchenili-bavshvebida-gamcarebuli-mshoblebi-mougvarebeli-problemis-mizezebi-da-shedegebi/ Accessed: 12.11.2019.

DUNN CAVELTY, Myriam. Europe's cyber-power. European Politics and Society, 2018, vol. 19 , no. 3, pp. 304-320.

E-Governance Academy. NCSI-National Cyber Security Index, 2018. Online; Available at: https://ega.ee/wp-content/uploads/2018/05/ncsi_digital_smaller.pdf; Accessed: 15.09.2019.

European Union Agency for Cybersecurity (ENISA). National Cybersecurity Strategies Evaluation Tool. Available at: https://www.enisa.europa.eu/topics/national-cybersecurity-strategies/national-cyber-security-strategies-guidelines-tools/nationalcyber-security-strategies-evaluation-tool Accessed: 10.11.2019.

HEEKS, Richard. Understanding e-governance for development. Manchester: Institute for Development Policy and Management, 2001.

International Telecommunication Union. Global Cybersecurity Index (GCI) 2017. Online; Available at: https://www.itu.int/dms_pub/itu-d/opb/str/D-STR-GCI.012017-PDF-E.pdf; Accessed: 15.09.2019.

International Telecommunication Union. Global Cybersecurity Index (GCI) 2018. 
Online. Available at https://www.itu.int/dms_pub/itu-d/opb/str/D-STR-GCI.012018-PDF-E.pdf; Accessed: 15.09.2019.

International Telecommunication Union. Definition of cybersecurity. Online; Available at: https://www.itu.int/en/ITU-T/studygroups/com17/Pages/cybersecurity.aspx; Accessed: 15.09.2019

KERIKMÄE, Tanel \& RULL, Addi. The Future of Law and eTechnologies. Heidelberg: Springer-Verlag, 2016.

KERIKMÄE, Tanel, HOFFMANN, Thomas, CHOCHIA, Archil. Legal Technology for Law Firms: Determining Roadmaps for Innovation. Croatian International Relations Review, 2018, vol. 24, no. 81, pp. 91-112.

LEPIK, Toomas \& TABATADZE, David. Estoniana \& Georgian Cyber Attacks. $21^{\text {st }}$ Annual FIRST Conference, Kyoto, June 28 - July 3, 2009. Online, Available at: https:// www.first.org/resources/papers/conference2009/lepiktabatadze-sliders.pdf Accessed: 15.10.2019.

LOMIDZE, Irakli. Cyber Attacks Against Georgia. Report for Georgian It Innovations; Online; Data exchange agency, 2011; Retrieved from: http://dea.gov.ge/uploads/ GITI\%202011/GITI2011_3.pdf; Accessed: 15.09.2019.

LUIIJF, Eric, BESSELING, Kim, SPOELSTRA, Maartje, GRAAF, Patrick. Ten National Cyber Security Strategies: a Comparison: Critical Information Infrastructure Security, 2013.

MADON, Shirin. Evaluating the developmental impact of e-governance initiatives: An exploratory framework. The Electronic Journal of Information Systems in Developing Countries, 2004, vol. 20, no. 1, pp. 1-13.

Ministry of Defence of Georgia. Threat Assessment Document for 2010-2013. Retrieved from: https://mod.gov.ge/uploads/2018/pdf/TAD-ENG.pdf Accessed: 02.10.2019.

Ministry of Defence of Georgia. Cyber Security Bureau. Retrieved from: https://mod.gov. ge/en/page/59/cyber-security-bureau Accessed: 02.10.2019.

Ministry of Internal Affairs of Georgia. Actions carried out by the ministry of internal affairs of Georgia. Retrieved from: https://police.ge/en/projects/kiberdanashauli/ shinagan-saqmeta-saministros-mier-gankhortsielebuli-ghonisdziebebi Accessed: 02.10 .2019

MIRKOVIC, Jelena. \& REIHER, Peter. A taxonomy of DDoS attack and DDoS defense mechanisms. ACM SIGCOMM Computer Communication Review, 2004, vol. 34, no. 2, pp. 39-53.

North Atlantic Treaty Organization (NATO). Cyber defence. Online. Retrieved from: https://www.nato.int/cps/en/natohq/topics_78170.htm; Accessed: 20.10.2019

PALVIA, Shailendra. \& SHARMA, Sushil. E-government and e-governance: definitions/ domain framework and status around the world. In International Conference on E-governance, 2007, pp. 1-12.

RIOS, Billy. Sun Tzu was a hacker: An examination of the tactics and operations from a real world cyber attack. In: CZOSSEC, Christian \& Geers, Kenneth (Eds.) The Virtual Battlefield: Perspectives on Cyber Warfare, 2009, vol. 3, pp. 143-155.

SCHLAMP, Johann. HOLZE, Ralph. JACQUEMART, Quentin. HEAP: reliable assessment of BGP hijacking attacks. IEEE Journal on Selected Areas in Communications, 2016, vol. 34, no. 6, pp. 1849-1861.

SVANADZE, Vladimer. Akhali gamotsveva saqartvelos internet sivrcistvis [sbsmo 
ICLR, 2019, Vol. 19, No. 2.

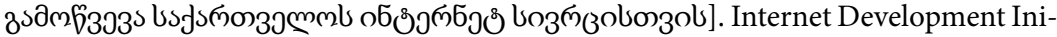
tiative - IDI, 2015. Retrieved from: http://indein.net/wp-content/uploads/2015/09/ New-Challenges-for-Georgian-Cyber-Space.pdf; Accessed: 15.09.2019;

TAMBUR, Silver. How Estonia became a global heavyweight in cyber security, 2017. Online. Available at: http://estonianworld.com/security/estonia-became-globalheavyweight-cyber-security/; Accessed: 16.09.2019;

TOLBERT, Caroline J., and MOSSBERGER, Karen. The effects of e-government on trust and confidence in government. Public administration review, 2006, vol. 66, no. 3, pp. 354-369.

UN E-Government Survey 2010; Online. Available at: https://publicadministration.un.org/egovkb/en-us/Reports/UN-E-Government-Survey-2010; Accessed: 16.09.2019.

UN E-Government Survey 2018. Online. Available at: https://publicadministration.un.org/egovkb/en-us/Reports/UN-E-Government-Survey-2018; Accessed: 16.09.2019.

VALUCH, Jozef; GÁBRIŠ, Tomáš; HAMULÁK, Ondrej. Cyber attacks, information attacks, and postmodern warfare. Baltic Journal of Law \& Politics, 2017, vol. 10, no. 1, pp. 63-89.

VALUCH, Jozef; HAMULÁK, Ondrej. Abuse of cyberspace within the crisis in Ukraine." The Lawyer Quarterly, 2018, vol. 8, no. 2, 94-107.

ZINETS, Natalia. Ukraine hit by 6,500 hack attacks, sees Russian 'cyberwar', Reuters. Online, Retrieved from: https://www.reuters.com/article/us-ukraine-crisiscyber/ukraine-hit-by-6500-hack-attacks-sees-russian-cyberwar-idUSKBN14I1QC Accessed: 17.10.2019.

\section{Timeline of Cybersecurity Development in Georgia}

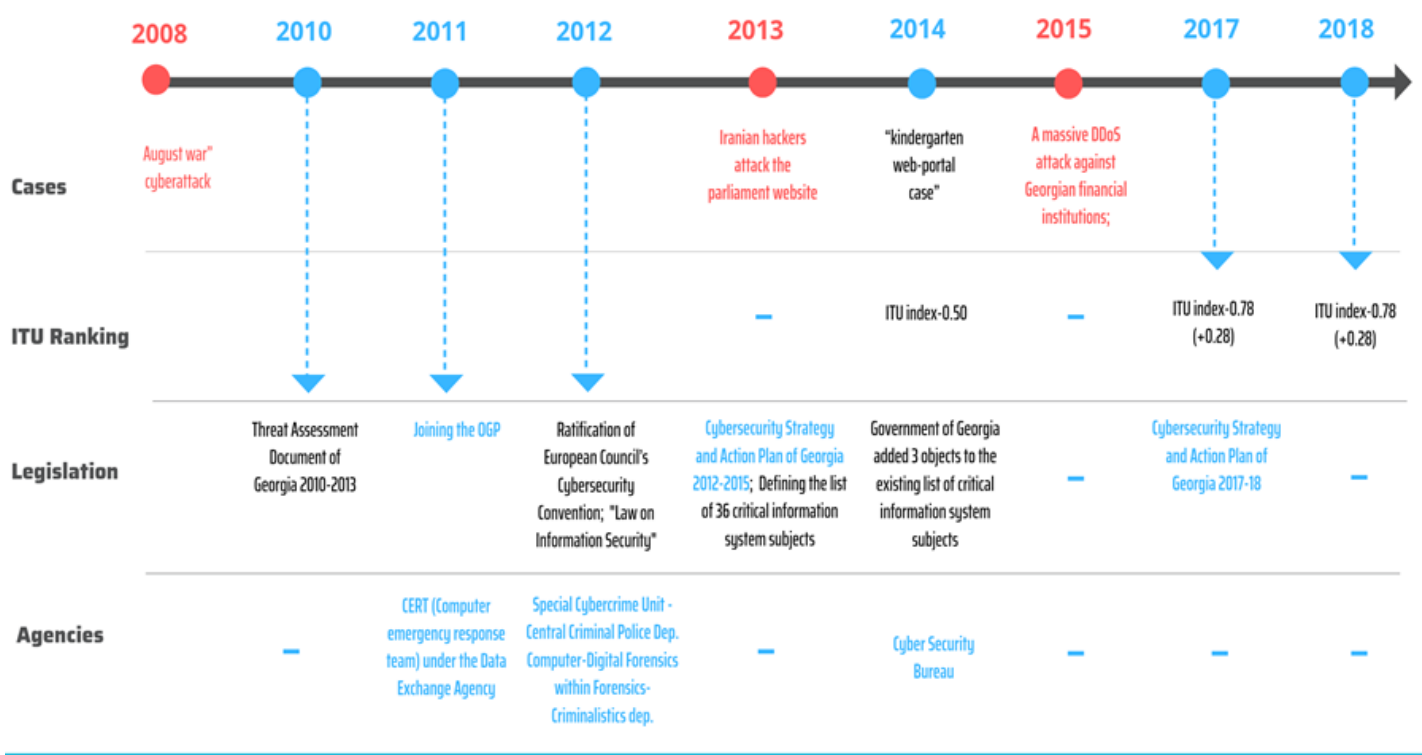

